\title{
ARTICLES
}

Submitted 19.09.2018. Approved 21.11.2018.

Evaluated by double blind review process.

DOI:http://dx.doi/10.12660/joscmv11n2p101-113

\section{THE MODERATE EFFECT OF ANALYTICS CAPABILITIES ON THE SERVICE QUALITY}

\begin{abstract}
This paper intends to analyze the moderate effect of organizational analytics capabilities in the development and service delivery processes, using as reference the gaps described in the Service Quality Model developed by Parasuraman, Zeithaml and Berry (1985). As a result of the analysis, five theoretical propositions were proposed, which elucidate the existing relationships between analytics capabilities and the Service Quality Model gaps, in order to generate future empirical research.
\end{abstract}

KEYWORDS | Organizational analytics capabilities, service quality, gaps, theoretical essay, business analytics.

\author{
Laís Rocha Vale \\ lais.r.vale@gmail.com \\ Larissa Alves Sincorá \\ larissa_sincora@hotmail.com \\ Letícia de Sousa Milhomem \\ leticiasmilhomem@gmail.com
}

Universidade Federal do Espírito Santo, Vitória, ES, Brazil 


\section{INTRODUCTION}

The use of data to make decisions in companies of different sectors and sizes is an increasing reality in worldwide markets, and according to Bayrak (2015), the ability to manage big data will be the core competency of companies. Therefore, not only enterprises related to information technology will be able to create and improve their products and services based on data analysis, but in fact any company in any business (Davenport \& Dyché, 2013).

The skill to manage Big Data may be translated into Organizational Analytics Capabilities, that are described by Davenport, Cohen, and Jacobson (2005) as a portfolio of data analytics methods and tools. The presence of these capabilities in an organization means that it has technical skills and ability to collect relevant data, use data analytics statistical models and, most importantly, the capacity for doing simulations and using those analyses to make strategic decisions.

In line with this, Bayrak (2015) affirms that the development of organizational analytics capabilities helps expanding the offer of products and services, and when developing an analytics culture, organizations may increase service quality, reduce operational costs and increase return on assets (IBM, 2017).

From these perspectives present in the literature, that point towards the influence of analytics capabilities on the delivery of services, this paper intends to study the following research question: the existence of organizational analytics capabilities can cause impact in the service quality perceived by customers? This question becomes relevant, since the understanding of the factors that influence the clients' perception of quality, and the inclusion of those factors in the service compound, is a determining matter to the success of service companies.

The choice of the service sector as the object of analysis was due to its importance to the national and global economy. Service companies are responsible for $68 \%$ of Brazilian GDP (Pereira, 2014) and they represent approximately $60 \%$ of the foreign trade in developed countries (MDIC, 2017). By developing an analytics organizational culture, service companies will be able to offer services that suit specific needs of the customers and, as a consequence, to obtain a better perception of quality from them.

Companies such as Boston Red Sox, Netflix, Amazon.com, CEMEX, Capital One, Harrah's Entertain- ment, Procter \& Gamble and Best Buy use analytics capabilities to build their competitive strategies, guide their decision-making processes and win the competition. When applying such analytics skills, those organizations identify the most profitable customers, accelerate the innovation of products and services, optimize the supply chains and the pricing (Davenport \& Harris, 2007).

In this study it will be used the concept of Perceived Service Quality, measured from the perception of quality by customers (Parasuraman, Zeitham, \& Berry, 1988), being the 5 Gaps model, proposed by Parasuraman et al. (1985), the tool used here. In this model Parasuraman et al. (1985) affirm that the perceived service quality is a result of the magnitude of the Gap 5 (the gap between the service offered by the companies and the service perceived by the customers), and this one depends on the magnitude of the other four Gaps, that may be favorable or unfavorable. The management of the service quality (Gap 5) depends, thus, on the control of the individual effect of each of the other gaps, being necessary to seek for tools that may minimize the negative effect that these gaps may cause on the service quality.

Therefore, the general objective of this study consists of analyzing the moderate effect of organizational analytics capabilities on the gaps described in the Service Quality Model of Parasuraman et al. (1985). In order to reach this general objective, it is proposed to identify the relevant dimensions to understand the "Service Quality" and "Organizational Analytics Capabilities" constructs, and the possible relationship between them. This understanding emerged from the results obtained in a systematic literature review, focused on the key topics of this paper, such as service quality, analytics capabilities, big data and business analytics.

For this purpose, first it is presented the theoretical frame, bringing a discussion about the "Service Quality", where it is presented the 5 Gaps Model of Parasuraman et al. (1985), and "Organizational Analytics Capabilities" constructs, presenting the variables that compose this last one. This literature review aims to dimension and delimitate the key concepts of the study. After that, it is carried out an analysis of the relationship between Organizational Analytics Capabilities and the 5 Gaps Model of Parasuraman et al. (1985), aiming to relate the existence of analytics behavior to each of the five gaps of the model, therefore presenting the theoretical propo- 
sitions and the structural model that evidences the relationship. Finally, there are the conclusions and suggestions for future research.

\section{THEORETICAL FRAME}

In order to define the theoretical discussion proposed by the research objective of this study, it was performed a literature review relevant to the discussion, aiming to delimitate the theoretical assumptions, the constructs and the relationships between the variables that compose the research model suggested. The theoretical frame serves as a basic theory to answer the research questions of this paper, as well as the foundation of the theoretical relationships presented in the research model.

\section{Service Quality}

To the majority of the service companies, the concern with quality has become a fundamental factor to develop the business strategy, because it has great influence on the company's performance and it impacts positively customers' satisfaction (Akbar \& Parvez, 2009; Bloemer \& Kasper, 1995; Huang, Tseng, \& Hsu, 2016; Johnston, 1995; Oliver, 1997; Orel \& Kara, 2014; Prado \& Marchetti, 1997; Spreng \& Mackoy, 1996; Sureshchandar, Rajendran, \& Anantharaman, 2002). Specifically to the service sector, delivering to the customer a service with superior quality has become a prerequisite to the success of this kind of business (Parasuraman et al., 1988), since, and unlike it happens with products, the perception of service quality occurs through the subjective analysis of who's consuming it, and not through specific physical characteristics that are easy to control, demanding, thus, an efficient structure of quality management, that enables the survival of the organization in its competitive market.

The processes of production and delivery of the service have particular characteristics that make it difficult to determine the aspects that define its quality. These characteristics are the intangibility, heterogeneity and inseparability of the production from the consumption (Grönroos, 1982; Parasuraman et al., 1985, 1988; Stefano, Casarotto Filho, Barichello, \& Sohn, 2015), and there is also the perishability as a fourth characteristic mentioned by some authors (Ghobadian, Speller, \& Jones, 1994). These characteristics refer to the fact that the process of service production occurs simultaneously with its consumption, turning the storage into something unlikely to happen and causing the customer to be an acting part of the production. Concerning the participation of the customer, it causes the service delivery to be heterogeneous, for each experience depends on the factors and actors involved. These characteristics turn the relationship between customers and a service company different from the relationship between a goods company and its clients (Grönroos, 1982).

Ghobadian et al. (1994) affirm that customers usually look for signs of quality in the products and services, that may be users' opinions, reputation, accessibility, communication, physical aspects, etc., but, specifically in the services, the influence of intangible aspects on the purchasing decision is much higher than the influence of tangible aspects on the purchase of a product. That causes service companies to have a greater responsibility to understand the aspects of the service that are interesting to their customers, to create expectations through external communication and to provide a service that matches, or excels, from the very first contact, the expectations that were created.

Customer's expectation is held as a standard which will be compared to the following experiences, resulting in an answer, that is the perceived service quality (Parasuraman, Berry, \& Zeithaml, 1993)Churchill, and Peter's (1993. To Ghobadian et al. (1994), the expectation is the image that the customer has of the service before consuming it, that may be influenced by external factors and, consequently, it may be shaped by the company through its efforts of marketing and communication with the client.

On the other hand, Johnston (1987) argues that the customer's expectation is dynamic, that is, it changes as the delivery stages advance, being influenced by different factors. To this author, expectation must be analyzed before the consumption experience, not measured after the experience, as proposed by Parasuraman et al. (1985) and corroborated by other authors.

This difference between the arguments referring to the use of expectation as a relevant factor to measure service quality represents a great divergence among the authors in this field. Regarding the measurement of the quality service construct, there are two main research lines that discuss in which way the quality service should be measured (Dabholkar, Shepherd, \& Thorpe, 2000; Santos, 2003)difference scores.

Some authors defend the disconfirmation, a concept proposed by Oliver (1980) and widely used in the lit- 
erature of service quality (Santos, 2003), as a way of measuring service quality, consisting of measuring the expectation of the customer and the perception of the service after the consumption, and the perceived quality is the result of the difference between the grades of the expectation and the perception (Grönroos, 1982; Parasuraman et al., 1985, 1988).

That way, having the service quality as a result of meeting customers' expectations, Parasuraman et al. (1988) developed a measurement scale called SERVQUAL, refined later by the authors (Parasuraman, Berry, \& Zeithaml, 1991), that measures the perceived service quality based on 5 determining factors. This scale is still the most used one in the relevant literature to analyze service quality (Mondo \& Fiates, 2013).

However, the SERVQUAL measurement scale has been criticized over time by some authors (Babakus \& Boller, 1992; Cronin Jr \& Taylor, 1994) that follow a second line of thinking, in which they believe that measuring only the customer perception, putting aside the expectation, is enough to measure service quality, which resulted in the creation of the SERVPERF (Cronin Jr \& Taylor, 1994), a scale similar to the SERVQUAL, but only with questions aimed at capturing customer's perception.

Brown, Churchill, and Peter (1993) also criticized the SERVQUAL scale, however they questioned its psychometric qualities, and they were promptly answered by Parasuraman et al. (1993), that, in the same edition of the Journal of Retailing, defended the validity of the scale. Dabholkar et al. (2000) point out that the SERVQUAL fails when assuming that the quality measure may be obtained with the average of the five dimensions that compose the scale, since in that way it does not capture the individual effect of the dimensions, as it treats the dimensions as components of the construct, not independent antecessors.

In this context of divergences regarding the measurement of service quality, many conceptual models of service quality have been developed (Beddowes, Gulliford, Knight, \& Saunders, 1987; Haywood-Farmer, 1988; Johnston, 1987; Moore, 1987; Nash, 1988; Parasuraman et al., 1985; Yang, Jun \& Peterson, 2004), with different intentions and applications, though, where some offer mechanisms for managers to implement and manage a quality control system, and others help realizing internal and external factors that influence the cus- tomer's service quality perception (Ghobadian et al., 1994).

Given the evolution of the discussion about service quality, there is currently (in the literature directed to the marketing area) the service quality management being treated as a topic that is slowly giving rise to what is called the service-dominant logic. According to Gummesson, Lusch, and Vargo (2010), quality is no longer a recurrent word in servicedominant logic, since the word "value" has taken its place. In this perspective, one intends to understand how the client creates value to himself from the consumption of the service (Grönroos, 2008).

In other areas, such as operations management, that also discusses about service quality (Jayaram \& Xu, 2016; Kress, \& Wisner, 2012; Wen, Prybutok, Blankson, \& Fang, 2014; Yang et al., 2004), there has been discussed the relationship of technology and its impacts on quality perception, bringing eService as a recurrent point of debate, since the growth of online services has caused the geography to have an even lesser role in the competitive strategy, causing the costs of changing suppliers to be linked to the convenience and utility of time, and promoting service quality to a factor even more relevant in the differentiation among competitors and in the attraction and retention of customers (Yang et al., 2004).

Nevertheless, despite the criticisms suffered over time and the new perspectives to the researches about service, the SERVQUAL scale is still largely used in studies about service quality (Chenet, Tynan, \& Money, 2000; Jamal \& Anastasiadou, 2009; Kumar, Tat Kee, \& Charles, 2010; Mohebifar, Hasani, Barikani, \& Rafiei, 2016; Stefano et al., 2015)namely conventional and Islamic, in terms of common critical factors after re-examining the SERVQUAL model, originally pioneered by Parasuraman. Further, the technique of dominance analysis is used to examine the relative importance of the critical factors in closing up the overall service quality gap in these two types of banks. Design/methodology/approach: The sample is made up of 308 bank customers, consisting of the customers from both Islamic and conventional banks from different parts of Malaysia. The data have been collected by using the structured questionnaire, which consists of three parts. Part 1 deals with consumers' usage of banking channels and their banking behaviour. Part 2 contains 26 statements related to service 
quality dimensions based on past literature. Finally, Part 3 contains the questions related to the sociodemographic profiles of respondents. Findings: The modified SERVQUAL model consists of four critical factors (dimensions. The service quality model developed by Parasuraman et al. (1985), which considers the existence of important gaps regarding the corporate executive's perception of the service quality and tasks associated with service delivery to customers, is still a valid basic theory to understand the obstacles in the processes of development and delivery of a service.

Therefore, this research adopts the traditional approach of disconfirmation, that quality can be measured from the difference between the expectation and perception of the service. This scale, when used in researches that intend to study a specific market, may be adapted to better represent the characteristic language of the environment researched, without losing, though, its backbone, that is the five dimensions of quality and its way of measuring the results. However, in this research, as it is not evaluating any market specifically, and because it considers the SERVQUAL scale a valid generic scale, there will be no adaptations.

In order to reach the research objective, which is to understand the impact of the organizational analytics capabilities on the five gaps of the Service Quality Model of Parasuraman et al. (1985), it is presented in the following section a further detailed explanation on the Service Quality Model of Parasuraman et al. (1985), analyzing each of the five gaps delimitated by the authors.

\section{Service Quality Dimensions - 5 Gaps Model}

Based on a research carried out with managers of companies related to four different sectors - retail bank, credit cards, securities brokerage and repair and maintenance of products and service - and their respective customers, Parasuraman et al. (1985) noticed along the research that there was a set of gaps linked to the perception of the managers about the service quality and the tasks related to the delivery of services to customers, and that those gaps could disrupt the delivery of a service of quality in the perspective of the customers.

Thus, they created a model that helps identifying the failures in the quality of the service, working as a diagnosis tool (Ghobadian et al., 1994). The first gap (Gap 1) is the "difference between the customers' expectations and the perceptions of the managers about the customers' expectations" (Parasuraman et al., 1985, p. 44). This gap exists when the manager has an inconsistent perception about what the customer really wants, and the reason of its existence is the lack of focus properly directed to the market (Ghobadian et al., 1994). Huang et al. (2016) refer to this gap as the knowledge gap.

The second gap (Gap 2) is "the difference between the perceptions of the managers regarding the customers' expectations and the definition of the service quality specifications" (Parasuraman et al., 1985, p. 45). This occurs when the managers cannot specify the proper standards to the service, so that they are in accordance with the customers' expectations (Huang et al., 2016. According to Parasuraman et al. (1985); there is often the knowledge of the expectations, but it lacks the means to meet them. Huang et al. (2016) refer to this gap as the design gap.

The third gap (Gap 3) is "the difference between the service quality specifications and the effective delivery of the service" (Parasuraman et al., 1985, p. 45). This gap occurs when the service delivered is different from the service designed by the manager. Parasuraman et al. (1985) points out that, in their research, the managers acknowledged that the employees of a service company have a strong influence on the perceived quality and that it is not always possible to standardize the service delivered. Huang et al. (2016) refer to this gap as the performance gap.

The fourth gap (Gap 4) is "the difference between the real delivery and the external communications about the service" (Parasuraman et al., 1985, p. 46). Parasuraman et al. (1985) points out that it is necessary to pay attention to not promote a service with more benefits than it can be delivered, because it raises the expectation and, when they are not met, it causes lower perceptions of quality. Huang at al. (2016) refer to this gap as the communication gap.

The fifth, and last, gap (Gap 5) is "the difference between the customer's perception related to his experience and his expectation about the service" (Huang et al., 2016, p. 88), and this gap is affected by the previous 4 (Huang et al., 2016; Parasuraman et al., 1985)based on the relevant literature and the operational features of air freight carriers, the service requirement attributes (SRAs. Parasuraman et 
al. (1985) refer to this gap as the service quality perceived by the customer.

In the model presented by the authors (Figure 1), the gaps shown as Gap 1, Gap 2, Gap 3 and Gap 4 occur during the stage of design and delivery of the service, being caused, thus, by the managers. Regarding Gap 5, that measures the perceived service quality, it is caused by the customer.

Figure 1. Service quality model

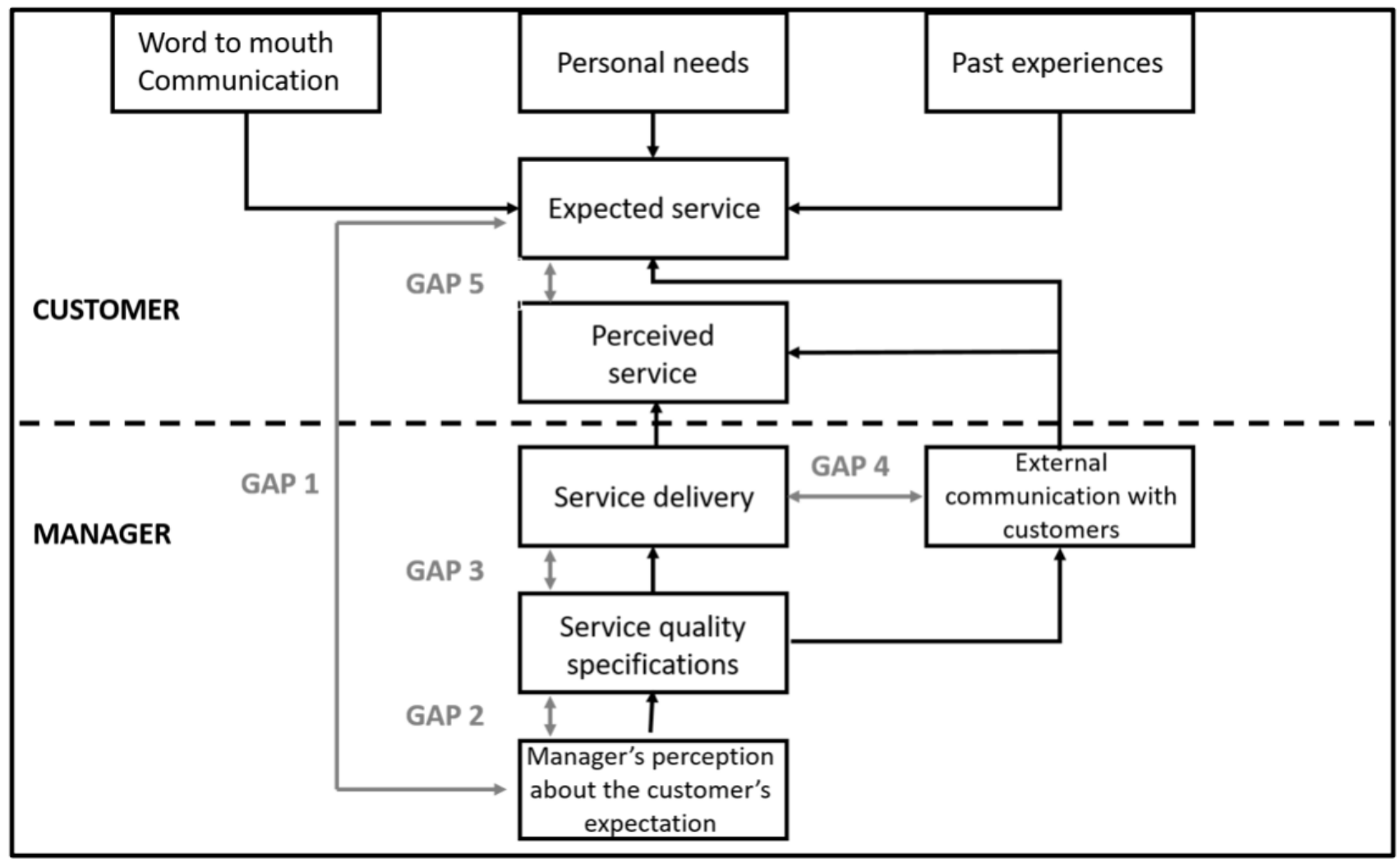

Source: Parasuraman, Zeithaml and Berry (1985). Adapted by the authors.

The manager is not capable of foreseeing all the needs and desires of all its customers and adjusting the offers according to the necessary level to meet those demands (Parasuraman et al. 1985). Therefore, the use of tools that help monitoring and gathering information about the customers is fundamental, allied with the development of analytics capabilities that can effectively bring advantages to the organization. Thus, aligned to this understanding, it is discussed in the next section about the concept of Organizational Analytics Capabilities and the strategic importance of developing those to the organizations.

\section{Organizational Analytics Capabilities}

In order to be successful in the activities of analysis and extraction of valuable information from data, it is necessary to develop more than just generic practices rec- ommended by specific knowledge corpus. It is needed to develop an entrepreneurial culture that values decision-making based on data (Davenport, 2006), so that it is possible to provide results, identify better market opportunities and make assertive decisions.

In the current globalized scenario, with fast communication and easy access to information, companies have started to own a great amount of data available, but in most cases they cannot turn those data into useful strategic information (Azimuddin \& Karunesh, 2011). Organizations face different types of problems in their routines, which demand fast and precise decision-making, and that may demand from the manager a series of abilities and skills to access the best solution given the information available.

These abilities and skills to extract relevant information from data are called analytics capabilities and 
this concept emerges from the discussions about Business Analytics (BA) (Sincorá, 2016; Sincorá, Oliveira, Zanquetto-Filho, \& Ladeira, 2018). Analytics capabilities are part of a set of variables that form the BA construct, that, in its turn, is seen as a sub-group of Business Intelligence (BI) (Azimuddin \& Karunesh, 2011; Longo, Giacovelli, \& Bochicchio, 2014), this one being defined as "an umbrella term for an enterprise-wide set of systems, applications and governance processes that enable sophisticated analytics, by allowing data, content, and analysis to flow to those who need them, when they need them" (Azimuddin \& Karunesh, 2011).

BA is defined by Khan and Saxena (2011) as a critical component of BI, because, through technologies and processes, it extracts relevant information from data to analyze business performance. Corroborating with the previous definition, Longo et al. (2014) define BA as being responsible for creating, in organizations, "capabilities to be competitive through processes and procedures, that can be used to analyze data, in order to improve business performance through facts-based decision-making" (Longo et al., 2014).

The BA concept became stronger after Davenport's publication of the paper named "Competing on Analytics" in 2006 in the Harvard Business Review (Bronzo et al., 2013) and, since then, it has been gaining notorious space among management paradigms (Delen \& Demirkan, 2013). That occurs because companies have been increasing the generation, storage and sharing of data, and BA proposes, among other things, the possibility of data capitalization (Bayrak, 2015), for organizations stop spending money solving problems to seek to optimize the use of their capital (Davenport, Cohen, \& Jacobson, 2005).

However, in order to have an organizational strategy addressed to optimization and with an implemented analytics culture, it is necessary to use the available data volume, be capable of analyzing those data, understand and make predictions based on that analysis and use the information generated as a support, or input, to the decision-making, besides having professionals who are technically capable of understanding the importance of data usage for the decision-making (Davenport et al., 2005) and extracting value from data. If the analytics perspective is not present in the company at the strategic level, the decision-maker will not know in which data he should focus or which goal must be achieved with the data analytics (Davenport, Harris, De Long, \& Jacobson, 2001).

In their research, SAS (2013) and Davenport et al. (2005) highlighted, respectively, metrics and steps to understand the analytics efficiency level of the companies and the necessary characteristics to compete analytically. Those metrics and steps presented in these two studies have several common points that, in short, discuss the adoption of technology, processes, big data, analytics business strategy and the need for having analytics capabilities able to operationalize all these tools.

Analytics capabilities, a characteristic pointed out by Davenport et al. (2005) as one of those which form the BA construct, and the focus of this section, are described as "(...) a portfolio of analytics methods and tools. They include tools that support traditional ad hoc queries, inferential statistics, predictive analytics, simulation, and optimization, thus supporting descriptive, diagnostic, predictive and prescriptive analytics" (Acito \& Khatri, 2014, p. 567). Sincorá $(2016 ; 2015)$ when performing a mapping of the scientific productions in BA of the last 11 years (2004 to 2015), aiming to define the variables that compose the organizational analytics capabilities, concluded that organizational analytics capabilities refer to a second order construct formed by three first order constructs, which are: statistical capabilities, business capabilities, and information technology capabilities. In this study it will be adopted the organizational analytics capabilities concept presented by Sincorá et al. (2018).

To Sincorá et al. (2018), statistical capabilities are the "ability to develop logical, critical and analytical reasoning about the organizational reality based on quantitative data" (p. 38), and their indicators are the elaboration of inquisitive, descriptive, predictive and prescriptive analyses. Business capabilities are the ability of making decisions based on data and facts, that is, extracting information from the available data, so that it helps identifying problems, developing and implementing solutions. Their indicators are: "clear communication of business problems; data translation into business perceptions; interpretation of analyses from statistical models; and decision-making based on facts and data" (Sincorá et al., 2018, p. 38-39).

Information technology capabilities are described as the existence of technical skills enabling the use of hardware and software that allow making com- 
putational modeling, having as indicators: "data exploration; data hygiene; data integration; and creation of big data environments" (Sincorá et al., 2018, p. 39-40).

Therefore, the present study focuses on understanding the way in which the existence of analytics capabilities in service companies may impact the existing gaps in the process of designing and delivering the service, described in the model of Parasuraman et al. (1985), presented in the previous section. In order to do so, the next section discusses the way in which the analytics capabilities can relate to the 5 Gaps Model, where it is presented the theoretical propositions, final objective of this paper.

\section{Organizational Analytics Capabilities and the 5 Gaps Model}

Many researches about BA, BI and Big Data have been showing that the adoption of analytics strategies and tools and the development of analytics capabilities create positive results in organizations (Chae, Yang, Olson, \& Sheu, 2014; Thomas H. Davenport, 2006; IBM, 2012, 2017; Lavalle, Lesser, Shockley, Hopkins, \& Kruschwitz, 2011; SAS, 2013). LaValle et al. (2011) in their research, to which it was interviewed 3,000 corporate executives of companies with different sizes and nationalities, reported that companies which declared having a superior performance over their competitors, have used BA in their activities five times more than the ones which declared having a lower performance.

IBM (2012), together with the Saïd Business School of Oxford University, conducted a study with 1,144 information technology companies and professionals in 95 countries, where it was asked which were the main functional objectives to use big data in their organizations. As a result, $49 \%$ of the interviewees affirmed that the main objective was to achieve customer-focused results, which demonstrates the important role of data usage and the development of analytics capabilities to understand and predict customers' behavior, therefore, improving their experience.

For service companies, that have strategies addressed to seek customer-focused results, the necessity of understanding customers' behavior and predicting their choices is essential, because quality perception, as seen before, depends on the previous expectation of the customers, and understanding which are these expectations is crucial to the success of these organizations.

Those information about the customer together with the development of statistical, business and information technology capabilities, support the manager to create a more realistic image of the customer's preferences and demands, causing a sensible reduction in the gap between the service expected by the customer and the manager's perception about this customer's expectation, that is, in the Gap 1 of the model of Parasuraman et al. (1985). This way, it is introduced the first proposition of this study:

P1: The existence of organizational analytics capabilities moderates the relationship between the manager's perception about the customer's expectation and the service expected by the customer (Gap 1), diminishing the gap between these two constructs.

The development of analytics capabilities in organizations may increase service quality, reduce operational costs and increase return on assets (IBM, 2017), besides supporting the expansion of products and services offer (Bayrak, 2015). Nevertheless, many companies have not used this analytics approach yet, and keep dealing with manual tools and intuitive management, to draw conclusions about data and act to improve operations (IBM, 2017), which turns up to be an under-usage of the collected data, missing to extract valuable information to the decision-making. Corroborating with this perspective, Davenport and Dyché (2013) say that "the primary value from big data comes not from the data in its raw form, but from the processing and analysis of it and the insights, products, and services that emerge from analysis."

Therefore, based on these discussions, it is possible to affirm that the development of statistical, business, and technology capabilities support the creation of new services, causing the manager to create or improve products that have the characteristics necessary to meet the customer's demand, besides promoting the essential conditions so that the customer has access to these characteristics and he is able to notice that his expectations were met, during the delivery of the service. That way, there are the second and third propositions:

P2: The existence of organizational analytics capabilities moderates the relationship between the 
manager's perception regarding the customer's expectation and the development of the specifications (design) of the service that will be delivered (Gap 2), diminishing the gap between these two constructs.

P3: The existence of organizational analytics capabilities moderates the relationship between the service design and the service delivery (Gap 3), reducing the gap between these two constructs.

According to what has been discussed along this paper, customer's quality perception depends on several stimuli that build the customer's expectation and the image that he has of the service before consuming it, which may be influenced by factors such as personal needs, past experiences, word of mouth, market communication, image and price, and, consequently, it can be shaped by the company that provides the service, through efforts directed to marketing and external communication (Ghobadian et al., 1994).

Thus, it is possible to notice that the external communication about the service characteristics, which get to the client through marketing actions, are factors that influence on the creation of expectations related to the consumption of service, and, therefore, also influence on the perceived service quality. This way, the characteristics of the service that must be advertised are the ones related to the customer's desires and easily noticed by him during the production and consumption of the service, so that the organization does not communicate characteristics and benefits that is not able to provide or that will not be easily noticed.

In this context, the creation and observation of indicators to control the service production process quality helps the manager to understand the strengths and weaknesses of his processes and use this information to highlight the strengths in the advertisements. That is, the existence of organizational ana- lytics capabilities supports the creation of a realistic advertising, showing what is in fact offered to the customer, generating an expectation that can be achieved by the service that will be offered.

Therefore, using statistical, business and technology capabilities to create an efficient communication and, as a consequence, diminishing the gap between the characteristics of the service advertised and the characteristics of the service offered is fundamental, so that the perceived service quality is the best possible. So, it is presented the fourth proposition:

P4: The existence of organizational analytics capabilities moderates the relationship between external communication with customers and the service delivered (Gap 4), reducing the gap between these two constructs.

According to Parasuraman et al. (1985), the perceived service quality depends on the size and direction of Gap 5 (the gap between the service offered by the companies and the service perceived by the customers), and this one depends on the size and direction of the other four Gaps, that may be favorable or unfavorable. To improve service quality, represented in the model as the Gap 5, the manager needs to understand the individual effect of each of the four remaining gaps (Huang et al., 2016) and seek for tools that minimize the negative effect these four gaps may cause in the service quality. Therefore, it is presented the fifth proposition:

P5: The existence of organizational analytics capabilities moderates the relationship between the service expected and the service perceived by the customer (Gap 5), reducing the gap between these two constructs.

This way, the research model and the propositions presented in this section are represented in Figure 2. 
Figure 2. Initial structural model and propositions

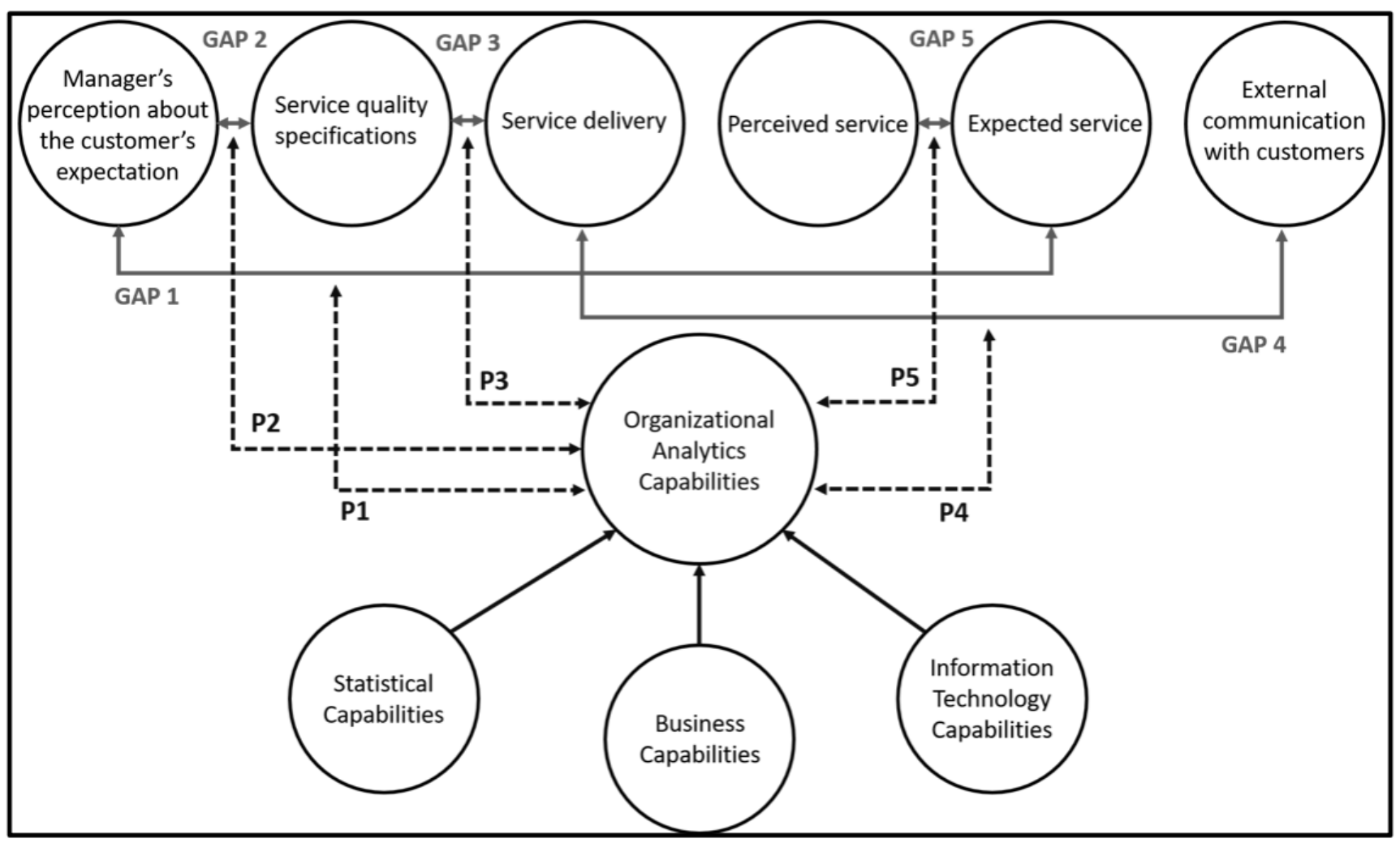

\section{METHODS}

This theoretical essay has a critical, reflexive, and positioned approach, since, based on the results obtained from a systematic literature review, it was possible to draw lines and structures to discuss the theme of this text: the moderate effect of analytics capabilities on the service quality.

This way, it was carried out a mapping of scientific productions on Service Quality and Business Analytics from the last six years (2013 to 2018) in three research databases in the field of Social Sciences (WEB OF SCIENCE; CAPES SCIENTIFIC JOURNALS and GOOGLE SCHOLAR). The articles were collected based on the use of the keywords "service quality", "service quality dimensions", business analytics", "business intelligence" and "big data", searching for the referred term in the title, abstract or keywords of the articles published in the databases consulted.

\section{FINAL CONSIDERATIONS}

The aim of this study was to propose a new analysis approach of the 5 Gaps Model of Service Quality suggested by Parasuraman et al. (1985), seeking to evaluate a possible relationship between the existence of organizational analytics capabilities and a shorter distance between the manager's understanding of the customer's needs, the specifications and delivery of the service, the customer's expectations and his perceptions after the consumption experience.

In order to better enlighten the proposed relationship, five theoretical propositions were created, which evidence the way in which analytics capabilities impact the perceived service quality. According to the propositions, as the analytics capabilities influence the perception of the customer's demand, service design, service delivery and in the way in which the service is communicated (gaps 1, 2, 3 and 4), it will also be impacting on the service quality perceived by the customer (gap 5). Therefore, these propositions corroborate with the idea exposed by IBM (2017), when it says that the development of an analytics culture may increase service quality, reduce operational costs and increase return on assets.

For management purposes this research is relevant because markets are quickly introducing new technologies that enable the improvement of data collection and management, but often do not invest in the development of organizational capabilities that are capable of turning this data into answers. Thus, 
this study focused on demonstrating the importance and the impact of those investments, aiming to stimulate them.

For academic purposes, the contribution occurs by opening new possibilities for empirical tests that can prove or refute the propositions presented here, therefore contributing to the discussions within the area of service quality and business analytics. It is suggested that future research study whether the presence of analytics capabilities is enough to create impact on the service quality or the maturity level of those capabilities would cause more impact on this relationship. The maturity level of the analytics tools in an organization has been discussed already, such as in the work of Davenport et al., (2005), and it is an interesting perspective to deepen the discussion proposed in the present paper.

Despite the contributions that this study may propose, limitations were found, such as the necessity of testing the propositions empirically. Based on empirical tests it will be possible to understand if the organizational analytics capabilities impact all the stages of the service development and delivery, present in the 5 Gaps Model, in a way that the customer can notice the improvements, or if the analytics capabilities allow internal improvements (with no less importance, though), with an impact that is only noticeable to the internal components of the organization. These tests could be performed based on quantitative research, aiming to validate the five propositions presented, or even qualitative research, that seek a deeper reflection on the relationship proposed between the constructs presented here.

In addition, this research aimed to demonstrate that the customer-oriented organizational focus, whether in the implementation of new processes, new technologies or creation of new services, is a decisive factor for a better evaluation of the service quality by customers.

NOTE: A preliminary version in Portuguese of this article was presented in the XXI Simpósio de Administração da Produção, Logística e Operações Internacionais (SIMPOI 2018) held at Fundação Getulio Vargas in São Paulo, Brazil.

\section{REFERENCES}

Acito, F., \& Khatri, V. (2014). Business analytics: Why now and what next? Business Horizons, 57(5), 565-570. doi:10.1016/j.bushor.2014.06.001
Akbar, M., \& Parvez, N. (2009). Impact of service quality, trust, and customer on satisfaction on customers' loyalty. $A B A C$ Journal, 29(1), 24-38.

Azimuddin, K., \& Karunesh, S. (2011). Business Intelligence: A new dimension to business. Pakistan Business Review, 13(2). Retrieved from https://www.computerweekly.com

Babakus, E., \& Boller, G. W. (1992). An empirical assesment of the SERVQUAL scale. Journal of Business Research, 24(3), 253-268.

Bayrak, T. (2015). A review of business analytics: A business enabler or another passing fad. Procedia-Social and Behavioral Sciences, 195, 230-239. doi:10.1016/j.sbspro.2015.06.354

Beddowes, P., Gulliford, S., Knight, M., \& Saunders, I. (1987)., University of Nottingham, Nottingham (6).

Bloemer, J. M. M., \& Kasper, H. D. P. (1995). The complex relationship between consumer satisfaction and brand loyalty. Journal of Economic Psychology, 16(2), 311-329. doi:10.1016/0167-4870(95)00007-b

Bronzo, M., Resende, P. T. V.de, Oliveira, M. P. V. de, McCormack, K. P., de Sousa, P. R., \& Ferreira, R. L. (2013). Improving performance aligning business analytics with process orientation. International Journal of Information Management, 33(2), 300-307. doi:10.1016/j.ijinfomgt.2012.11.011

Brown, T. J., Churchill, G. A., \& Peter, J. P. (1993). Improving the measurement of service quality. Journal of Retailing, 69(1), 127-139.

Chae, B., Yang, C., Olson, D., \& Sheu, C. (2014). The impact of advanced analytics and data accuracy on operational performance: A contingent resource based theory (RBT) perspective. Decision Support Systems, 59, 119-126. doi:10.1016/j.dss.2013.10.012

Chenet, P., Tynan, C., \& Money, A. (2000). The service performance gap: Testing the redeveloped causal model. European Journal of Marketing, 34(18), 472-497.

Cronin Jr., J. J., \& Taylor, S. A. (1994). SERVPERF versus SERVQUAL: Reconciling performance-based and perceptions-minus-expectations measurement of service quality. The Journal of Marketing, 58(1), 125-131.

Dabholkar, P. A., Shepherd, C. D., \& Thorpe, D. I. (2000). A comprehensive framework for service quality: An investigation of critical conceptual and measurement issues through a longitudinal study. Journal of Retailing, 76(2), 139-173. doi:10.1016/s0022-4359(00)00029-4

Davenport, T. H. (2006). Competing on analytics. Harvard Business Review, 84(1), 99-107.

Davenport, T. H., Cohen, D., \& Jacobson, A. (2005). Competing on analytics. Working Knowledge Research Report, 1-12.

Davenport, T. H., \& Dyché, J. (2013). Big data in big companies. International Institute for Analytics. Retrieved from https://docs.media.bitpipe.com/io_10x/io_102267/ item_725049/Big-Data-in-Big-Companies.pdf

Davenport, T. H., \& Harris, J. G. (2007). Competing on Analytics: The new science of winning. Boston, MA: Harvard Business School Press. 
Davenport, T. H., Harris, J. G., De Long, D. W., \& Jacobson, A. L. (2001). Data to knowledge to results: Building an analytics capability. California Management Review, 43(2), 117138. doi: $10.2307 / 41166078$

Delen, D., \& Demirkan, H. (2013). Data, information and analytics as services. Decision Support Systems, 55(1), 359-363. doi:10.1016/j.dss.2012.05.044

Ghobadian, A., Speller, S., \& Jones, M. (1994). Service quality: Concepts and models. International Journal of Quality \& Reliability Management, 11(9), 43-66. doi:10.1108/02656719410074297

Grönroos, C. (1982). An applied service marketing theory. European Journal of Marketing, 16(7), 30-41. doi:10.1108/ EUM0000000004859

Grönroos, C. (2008). Service logic revisited: Who creates value? And who co-creates? European Business Review, 20(4), 298-314. doi:10.1108/09555340810886585

Gummesson, E., Lusch, R. F., \& Vargo, S. L. (2010). Transitioning from service management to service-dominant logic. International Journal of Quality and Service Sciences, 2(1), 8-22. doi:10.1108/17566691011026577

Haywood-Farmer, J. (1988). A conceptual model of service quality. International Journal of Operations \& Production Management, 8(6), 19-29. doi:10.1108/eb054839

Huang, S. H. S., Tseng, W. J., \& Hsu, W. K. K. (2016). An assessment of knowledge gap in service quality for air freight carriers. Transport Policy, 50, 87-94. doi:10.1016/j.tranpol.2016.06.006

International Business Machines. (2012). Analytics: The realworld use of big data. Retrieved from https://www-935. ibm.com/services/us/gbs/thoughtleadership/ibv-big-dataat-work.html

International Business Machines. (2017). Descriptive , predictive, prescriptive: Transforming asset and facilities management with analytics. Retrieved from https://www-01.ibm.com/common/ssi/cgi-bin/ ssialias?htmlfid=TIW14162USEN

Jamal, A., \& Anastasiadou, K. (2009). Investigating the effects of service quality dimensions and expertise on loyalty. European Journal of Marketing, 43(3/4), 398-420.

Jayaram, J., \& Xu, K. (2016). Determinants of quality and efficiency performance in service operations. International Journal of Operations \& Production Management, 36(3), 265-285.

Johnston, R. (1987). A framework for developing a quality strategy in a customer processing operation. International Journal of Quality \& Reliability Management, 4(4), 37-46. doi:10.1108/eb006070

Johnston, R. (1995). The determinants of service quality: Satisfiers and dissatisfiers. International Journal of Service Industry Management, 6(5), 53-71. doi:10.1108/09564239510101536

Khan, A., \& Saxena, K. (2011). Business Intelligence: A new dimension to business. Pakistan Business Review, 13(2), 3942.
Kress, N., \& Wisner, J. (2012). A supply chain model for library quality and service improvement. Journal of Operations and Supply Chain Management, 5(2), 40-53.

Kumar, M., Tat Kee, F., \& Charles, V. (2010). Comparative evaluation of critical factors in delivering service quality of banks: An application of dominance analysis in modified SERVQUAL model. International Journal of Quality \& Reliability Management, 27(3), 351-377. doi:10.1108/02656711011023320

Lavalle, S., Lesser, E., Shockley, R., Hopkins, M. S., \& Kruschwitz, N. (2011). Big Data, analytics and the path from insights to value. MIT Sloan Management Review, 52(2), 2132. doi:10.0000/PMID57750728

Longo, A., Giacovelli, S., \& Bochicchio, M. (2014). Fact Centered ETL: A proposal for speeding business analytics up. Procedia Technology, 16, 471-480. doi:10.1016/j. protcy.2014.10.114

Ministério da Indústria, Comércio Exterior e Serviços. (2017). A importância do Setor Terciário. Recuperado de http:// www.mdic.gov.br/index.php/comercio-servicos/a-secretaria-de-comercio-e-servicos-scs/402-a-importancia-dosetor-terciario

Mohebifar, R., Hasani, H., Barikani, A., \& Rafiei, S. (2016). Evaluating service quality from patients' perceptions: Application of importanceeperformance analysis method. Osong Public Health and Research Perspectives, 7(4), 233-238. doi:10.1016/j.phrp.2016.05.002

Mondo, T. S., \& Fiates, G. G. S. (2013). Os modelos de qualidade em serviços: Mapeamento da Produção científica de alto impacto para a área de Administração no Brasil até 2012, motivo de preocupação para os pesquisadores de Marketing? Anais Do XXXVII Encontro Da ANPAD, 1-16.

Moore, C. D. (1987). Outclass the competition with service distinction. Mortgage Banking, 47(11), 24-32.

Nash, C. A. (1988). A question of service: action pack. Business Management Programme, Hotel and Catering Industry Training Board, National Consumer Council, London.

Oliver, R. L. (1980). A cognitive model of the antecedents and consequences of satisfaction decisions. Journal of marketing research, 17(4), 460-469.

Oliver, R. L. (1997). Satisfaction: A behavioral perspective on the consumer. New York, NY: Mcgraw-Hill College.

Orel, F. D., \& Kara, A. (2014). Supermarket self-checkout service quality, customer satisfaction, and loyalty: Empirical evidence from an emerging market. Journal of Retailing and Consumer Services, 21, 118-129. doi:10.1016/j.jretconser.2013.07.002

Parasuraman, A., Berry, L. L., \& Zeithaml, V. A. (1991). Refinement and reassessment of the SERQUAL scale. Journal of Retailing, 67(4), 420-450. doi:10.1111/j.14388677.2010.00335.x

Parasuraman, A., Berry, L. L., \& Zeithaml, V. A. (1993). More on improving service quality measurement. Journal of Retailing, 69(1), 140-147. 
Parasuraman, A., Zeithaml, V. A., \& Berry, L. L. (1985). Model service its quality and implications for future. American Marketing Association, 49(4), 41-50.

Parasuraman, A., Zeithaml, V. A., \& Berry, L. L. (1988). Servqual: A multiple-item scale for measuring consumer perceptions of service quality. Journal of Retailing, 64(1), 12-40.

Pereira, V. R. (2014). O setor serviços no Brasil. (Master's thesis, Universidade Estadual Paulista Júlio de Mesquita Filho), Araraquara, São Paulo, Brasil.

Prado, P. H. M., \& Marchetti, R. (1997). Excelência em supermercados: A dimensão da satisfação do consumidor. Revista de Administração, 32(2), 58-64.

Santos, J. (2003). E-service quality: A model of virtual service quality dimensions. Managing Service Quality: An International Journal, 13(3), 233-246. doi:10.1108/09604520310476490

Sas Analytics. (2013). Assessing your business analytics initiatives. Retrieved from http://enterpriseittools.com/sas2// Assessing\%20your\%20business\%20analytics\%20initiatives.pdf

Sincorá, L. A. (2016). Capabilidades Analíticas Organizacionais: Um estudo do impacto na relação entre maturidade de gestão de processos de negócio e resiliência organizacional. Master's thesis, Universidade Federal do Espírito Santo, Vitória, Espírito Santo, Brasil.
Sincorá, L. A., Carneiro, T. C. J., \& Oliveira, M. P. V. de. (2015). Business Analytics: How's and whither will go? In 12th CONTECSI - International Conference on Information Systems and Technology Management (pp. 1-23). São Paulo, SP.

Sincorá, L. A., Oliveira, M. P. V. de, Zanquetto-Filho, H., \& Ladeira, M. B. (2018). Business analytics leveraging resilience in organizational processes. Revista de Administração, 53(3), 385-403. doi:10.1108/RAUSP-04-2018-002

Spreng, R. A., \& Mackoy, R. D. (1996). An empirical examination of a model of perceived service quality and satisfaction. Journal of Retailing, 72(2), 201-214. doi:10.1016/ S0022-4359(96)90014-7

Stefano, N. M., Casarotto Filho, N., Barichello, R., \& Sohn, A. P. (2015). A fuzzy SERVQUAL based method for evaluated of service quality in the hotel industry. In Procedia CIRP (pp. 433-438). doi:10.1016/j.procir.2015.02.140

Sureshchandar, G. S., Rajendran, C., \& Anantharaman, R. N. (2002).Determinants of customer-perceived servicequality: A confirmatory factor analysis approach. Journal of Services Marketing, 16(1), 9-34. doi:10.1108/08876040210419398

Wen, C., R. Prybutok, V., Blankson, C., \& Fang, J. (2014). The role of E-quality within the consumer decision making process. International Journal of Operations \& Production Management, 34(12), 1506-1536.

Yang, Z., Jun, M., \& Peterson, R. T. (2004). Measuring customer perceived online service quality: Scale development and managerial implications. International Journal of Operations \& Production Management, 24(11), 1149-1174. 